\title{
The Fate of Chemical Pollutants with Soil Properties and Processes in the Climate Change Paradigm-A Review
}

\author{
Bhabananda Biswas ${ }^{1,2}$, Fangjie Qi ${ }^{2,3}$, Jayanta Kumar Biswas ${ }^{4}$, Ayanka Wijayawardena ${ }^{2,3}$ (D), \\ Muhammad Atikul Islam Khan ${ }^{1}$ and Ravi Naidu ${ }^{2,3, *}$ (iD) \\ 1 Future Industries Institute, University of South Australia, Mawson Lakes, SA 5085, Australia; \\ Bhaba.Biswas@unisa.edu.au (B.B.); muhammad.khan@mymail.unisa.edu.au (M.A.I.K.) \\ 2 Cooperative Research Centre for Contamination Assessment and Remediation of the Environment, \\ ACT Building, The University of Newcastle, Callaghan, NSW 2308, Australia; Fangjie.Qi@uon.edu.au (F.Q.); \\ ayanka.wijayawardena@newcastle.edu.au (A.W.) \\ 3 Global Centre for Environmental Remediation, the University of Newcastle, Callaghan, NSW 2308, Australia \\ 4 Department of Ecological Studies and International Centre for Ecological Engineering, University of Kalyani, \\ Kalyani, Nadia-741235, West Bengal, India; biswajoy2008@gmail.com \\ * Correspondence: Ravi.Naidu@crccare.com; Tel.: +61-02-4913-8705
}

Received: 29 June 2018; Accepted: 28 August 2018; Published: 1 September 2018

\begin{abstract}
Heavy metal(loid)s and organic contaminants are two major groups of pollutants in soils. The fate and exposure of such pollutants in soil depends on their chemical properties, speciation, and soil properties. Soil properties and processes that control the toxicological aspects of pollutants include temperature, moisture, organic matter, mineral fractions, and microbial activities. These processes are vulnerable to climate change associated with global warming, including increased incidences of extreme rainfall, extended dry periods, soil erosion, and a rise in sea level. Here we explain evidence that relates to the effects of climate change-driven soil processes on the mobility, transport, and storage of pollutants in soil. The review found that changes in climate could increase human exposure to soil contaminants mainly due to processes involving soil organic carbon (SOC), surface runoff, redox state, and microbial community. However, uncertainties remain in relation to the extent of contaminant toxicity to human health, which is linked to global change drivers.
\end{abstract}

Keywords: soil contaminants; soil process; climate changes; ecotoxicity of pollutants

\section{Introduction}

Manipulation of naturally available chemicals and the synthesis of new compounds has played a vital role in human development. However, conflict between the ever-increasing development of human civilization and the need to reduce chemical pollutants has become apparent since the development of the discipline of environmental toxicology in the middle of the 20th century [1]. Economic growth and the demand for goods has brought up approximately 80,000 synthetic chemicals over the last 50 years' time [2]. Synthetic chemicals produce goods and services for us but also emit contaminants to the environment. Every year 2000-3000 new chemicals are reviewed by the United States Environmental Protection Agency (US-EPA) and many are identified as hazardous [3,4]. The Earth's critical zone is defined as the "heterogeneous, near-surface environment in which complex interactions involving rock, soil, water, air, and living organisms regulate the natural habitat and determine the availability of life-sustaining resources" [5]. Soil dominates the flow and transformation of mass, energy, and genetic information [6], and therefore significantly dominates the above- and below- ground systems of this zone. In the Anthropocene, the age defined as that with significant 
human impacts on the environment, this critical zone is a front-line natural resource vulnerable to climate change [7]. The empirical and research data across various geochemical spaces suggest that climate change is one of the ten planetary boundaries [8] potentially impacting environmental sustainability [9-14]. Excessive production of greenhouse gases (GHG) (e.g., $\mathrm{CO}_{2}, \mathrm{~N}_{2} \mathrm{O}, \mathrm{NO}_{\mathrm{x}}, \mathrm{CH}_{4}$, etc.), which lead to global warming, changes the frequency and intensity of rainfall, drought, and the intensity of storms and soil erosion; all of which affect soil properties and functions $[15,16]$.

Climate change and its effects on public health are related to the exposure of environmental contaminants and pathogens that are discussed in a previous communication [17]. Also, in the marine food webs such relations revealed that the bioaccumulation and transfer of several contaminants (e.g., persistent organic pollutants) were altered due to climate change [18]. On the other hand, soil systems control several processes in performing ecological functions. In a recent review, Lipczynska-Kochany [19] stressed the effect of climate changes on humic substances, which had a potential link to the fate of contaminants in soil, surface, and groundwater. The author concluded that climate changes might enhance the biodegradation of humic substances and thus soil contaminants could be desorbed and re-immobilized [19]. Indeed, the exposure of soils to pollutants is critically important to aspects of the ecotoxicity of pollutants in soils [20]. However, from a toxicological perspective, the occurrence, fate, and transport of chemical pollutants in soils are largely driven by the properties of the pollutants; however, the properties of soils are also important. Therefore, in this review, we develop an understanding of the dynamics of pollutants in soils with various properties, subject to a range of processes under the climate change influences.

\section{Understanding Soil Properties and Processes and the Dynamics of Chemical Pollutants}

Toxic substances including heavy metal(loid)s, such as arsenic (As), mercury (Hg), lead (Pb), cadmium $(\mathrm{Cd})$, and chromium(VI) $(\mathrm{Cr}(\mathrm{VI}))$ and organic contaminants, such as polycyclic aromatic hydrocarbons (PAHs) (e.g., benzo[a]pyrene), persistent organic pollutants (POPs) (e.g., polychlorinated biphenyl) or emerging pollutants (e.g., per- and poly-fluoroalkyl substances, polybrominated biphenyls, etc. that present unique issues and challenges to environmental quality) have been detected in soils [21]. The available fractions of such pollutants in soil are often toxic to soil organisms and humans [22-24].

Adsorption and desorption of chemical pollutants in soils largely depend on $\mathrm{pH}$, redox conditions, and the available chemical species. Inorganic ions, such as $\mathrm{HPO}_{4}{ }^{2-}, \mathrm{NO}_{3}{ }^{-}, \mathrm{Cl}^{-}$, and $\mathrm{SO}_{4}{ }^{2-}$ and organic ligands, such as citrate, oxalate, fulvic, and dissolved organic carbon (DOC) can affect pollutant behavior in soils [25-27]. Inorganic ions can influence adsorption through their interactions with metal(loid)s. For example, metal(loid)s complexed with such ions exhibit less sorption affinity to soils [28] than free ions, but free states of some ions (e.g., $\mathrm{PO}_{4}{ }^{3-}$ ) in soil increase net negative surface charge and therefore increase the sorption of cationic metal(loid)s [29]. Soil organic constituents, such as soil organic matter (SOM), which is often estimated and expressed as soil organic carbon (SOC) [30], play an important role in the sorption of soil pollutants [31]. Some SOM, such as humic substances have a high affinity for metal cations [32]. The heavy metal ion-binding ability of humic substances is attributed to the negative surface charge, particle size, and diffusion coefficient of humic acid as well as the content of oxygen-containing functional groups, including $-\mathrm{OH},-\mathrm{COOH},-\mathrm{SH}$, and $-\mathrm{C}=\mathrm{O}[33,34]$.

Another important process in soil is the microbial activity relative to the fate and transformation of pollutants. For example, the microbial degradation of petroleum hydrocarbons [35] is experienced as the natural clean-up process of organic pollutants. Also, heavy metal(loid)s can be remediated using the soil-grown plants (commonly accepted as "phytoremediation"), particularly with the microbial-assisted rhizosphere [36]. 


\section{Changing Environments-Climate Change and the Soil Properties and Processes}

The principal climate change factors and results that affect soil properties and processes are (i) presence of GHG, (ii) air and soil warming or extreme surface temperature, (iii) extreme rainfall and saline water intrusion, and (iv) land and surface soil erosion [7,37-39]. The processes that can induce changes in soil properties and processes include temperature, hydrologic cycle, soil moisture, salinity, redox condition, and the organic carbon fractions of soil systems [20,40-45].

The IPCC [46] reported a significant increase in GHG, mainly during the last 60 years. For instance, during the past six decades, the anthropogenic $\mathrm{CO}_{2}$ emitted to the atmosphere was $2040 \pm 310 \mathrm{Gt}$, and the amount of $\mathrm{CH}_{4}$ and $\mathrm{N}_{2} \mathrm{O}$ followed with the similar trend [46] (Figure 1). However, a large portion of GHG is deposited in the terrestrial systems, such as soil and plants, which contribute soil organic carbon (SOC) pool in soil or increase $\mathrm{N}$ uptake in plant systems $[47,48]$. Soils are impacted by climate changes and the total environmental process involves air and water systems as well (Scheme 1). Climate change has induced an increase of global mean surface temperature by about $0.3-0.6{ }^{\circ} \mathrm{C}$ in the past century and is expected to remain elevated [46]. The warming of the atmosphere in the Anthropocene, which was particularly evident from 1983 to 2012 [46], is likely to have increased temperature in soils [16].

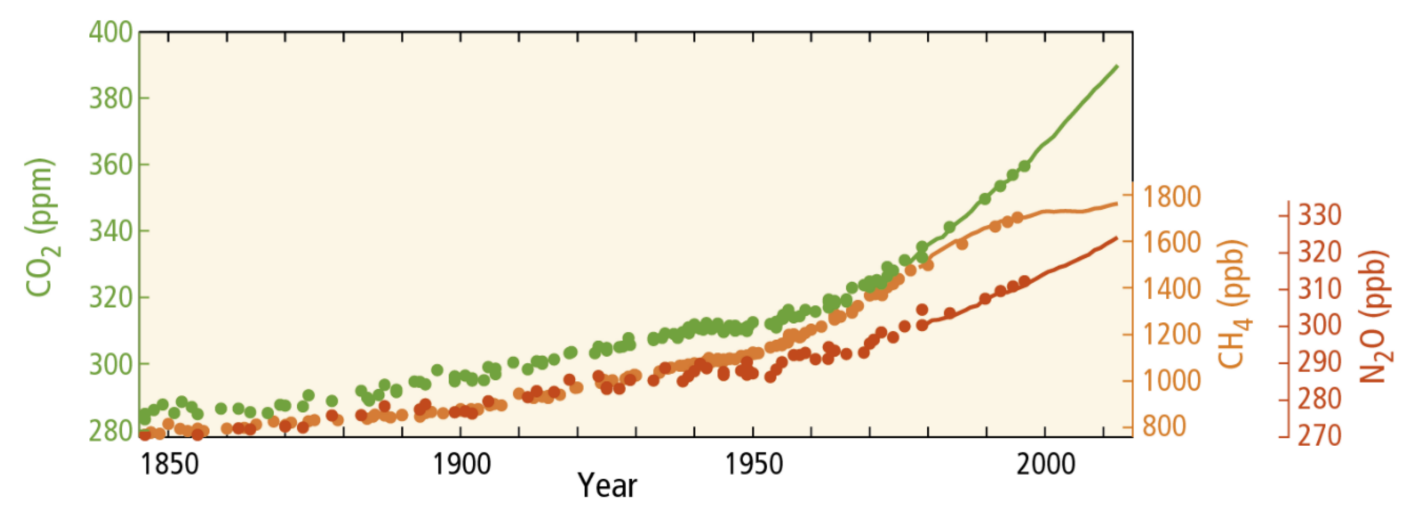

Figure 1. A global average greenhouse gas concentration trend. The figure was retrieved from the Intergovernmental panel on climate change with permission (IPCC [46]).

Temperature significantly influences the organic carbon dynamics of soils, imposing substantial loss to "no detectable" loss of soil organic carbon [49]. A considerable uncertainty exists on the soil carbon loss due to global warming as reported in the literature. The focus of our review avoids an explicit explanation of this aspect. However, Crowther et al. [50] reported that up to $1{ }^{\circ} \mathrm{C}$ of soil surface warming would lead to the loss of carbon ( $30 \pm 30$ petagrams to $203 \pm 161$ petagrams) from the upper soil horizons $(0-15 \mathrm{~cm})$. Furthermore, modeling predicted that the effects of elevated temperatures would slightly increase soil organic carbon (SOC) but decrease dissolved organic carbon (DOC) in the soils of forest systems, but both would decrease in agricultural soils [38]. Using a carbon-nitrogen model, Peng et al. [51] reported an overall decrease of SOC in the forest soils of north-eastern China in response to increased $\mathrm{CO}_{2}$ emissions and air temperature. However, in that case, the net primary productivity and carbon biomass were increased in the forest soil. In addition to temperature, other climate change-affected factors, such as hydrological process and the relative abundances of organic- $\mathrm{C}$ substances, influence the sensitivity of SOC decomposition in soils [52].

In the case of precipitation, the dissolved organic carbon (DOC) is affected higher than SOC [38]. The leaching rate of DOC is an important factor for assessing the effect of precipitation. Water-logging in an extreme precipitation event affects the carbon flux in soil and the plant's uptake of ambient $\mathrm{CO}_{2}$. Also, topsoil erosion, in this case, could accelerate this loss of particulate organic carbon and DOC [53].

The dynamics of $\mathrm{pH}$ in soil is slow in comparison to freshwater and ocean. The acidification of waterbodies is due to the anthropogenic addition of sulfuric and nitric acids (mainly through the 
oxidation of sulfur and nitrogen gas) and increased amount of atmospheric $\mathrm{CO}_{2}$ [54]. On the other hand, ion exchange by the available soil minerals buffers the soil $\mathrm{pH}$ and therefore the $\mathrm{pH}$ of soil does not change rapidly. From the climate change perspective, increased rainfall could accelerate the leaching of basic cations and thus increase soil acidity [55]. The deposition of atmospheric $\mathrm{N}$ coupling with acidic species $\left(\mathrm{SO}_{3}{ }^{2-}, \mathrm{NO}_{3}{ }^{-}\right.$, etc.) has a positive effect on soil acidification. In a field simulation experiment, Zheng et al. [56] reported that these acid dispositions decreased soil respiration by $0.23 \%$, which were further exacerbated up to $1.54 \%$, while both acid and $\mathrm{N}$ deposition occurred in soil.

As discussed in Sections 2 and 3, the contamination of soils by pollutants and their transport, diffusion, and persistence in soils are affected by physical, chemical and biological properties and processes [57] (Scheme 1). In the following sections, we will expound linkages among climate change drivers, soil processes, and the exposure of chemical pollutants from empirical and predictive research perspective.

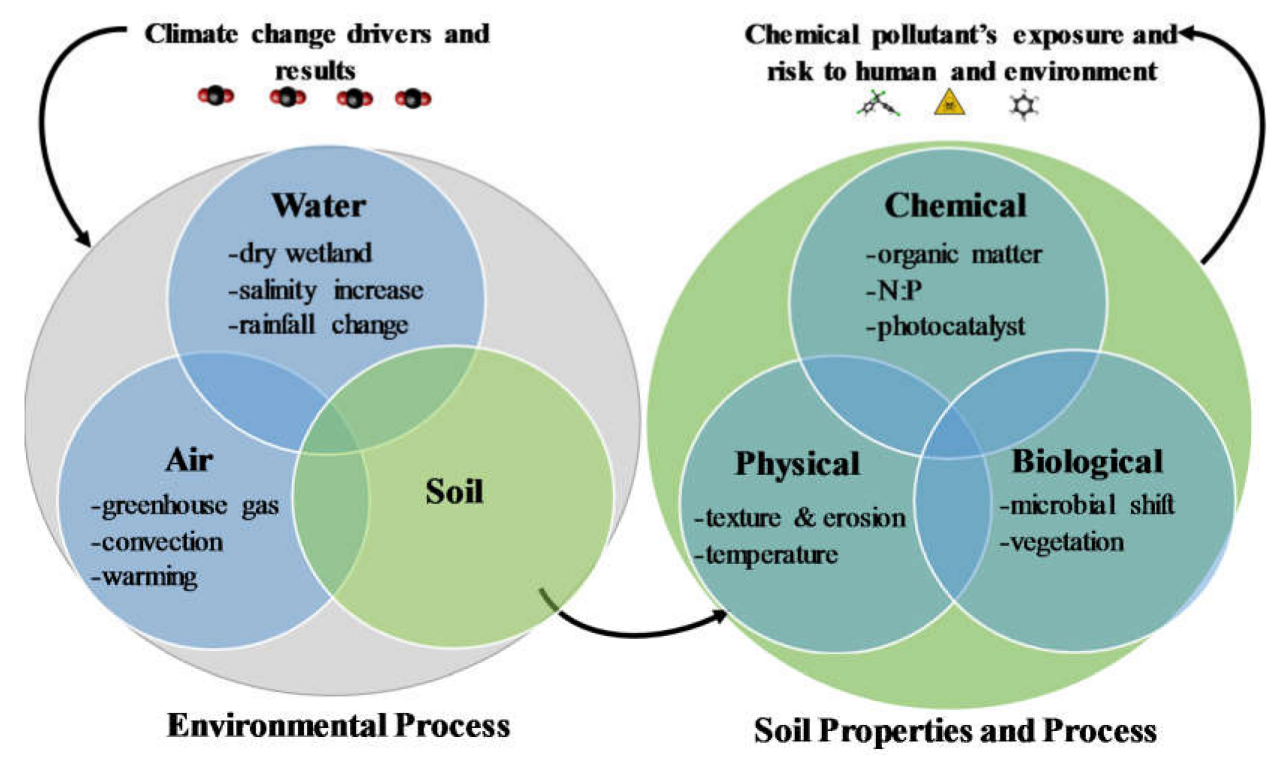

Scheme 1. The impact of climate change drivers on the soil dynamics, resulting in further risk to the exposure of chemical pollutants. The left circle indicates that climate changes and any factors responsible for climate changes influence soil properties and processes directly and via the atmosphere and hydrosphere. On the other hand, the right circle represents the physical, chemical, and biological processes involved in that soil system and the effects of these on the contaminants' fate and exposure.

\section{Effects of Climate Change on Soil Properties and Processes and the Exposure of Pollutants}

Under climate change scenarios, direct impacts on the fate of contaminants have been reported, especially on their transportation between the environmental compartments of the atmosphere, water, soil, sediment, and biota [18]. This occurs through physical, chemical, and biological processes, including possible dilution, concentration, and bifurcation of contaminants $[20,45,58]$. In addition, under climate change-induced alternations of soil conditions, climate can change surface runoff, air-surface exchange, wet and dry deposition, dissolution by rain, and the transformation of contaminants (e.g., photolysis, biodegradation, oxidation in air, and dilution) [20,43,59].

\subsection{Soil Temperature, Water, and Erosion}

In relation to the warming world, the changed and changing transport pathways of contaminants, including volatilization, precipitation, surface runoff, degradation and transformation have been well documented during the past decade $[20,45,58]$ (Scheme 2). Briefly, the major events are as follows: (i) In the atmosphere: persistent organic pollutants and particulate matters can be deposited into the soil and water by increased rainfall; (ii) Polar, ice and glacier region: increased temperature 
could increase the release and mobility of persistent organic pollutants towards the downstream; (iii) On soil surface: volatilization and degradation of organic contaminants are positively correlated to temperature; on the other hand, increased precipitation might increase runoff of contaminants from soil to water system; and (iv) In waterbodies: warming conditions could enhance the volatilization, hydrolysis, and microbial degradation of contaminants, while both temperature and acidic condition of water favor solubility of heavy metals in water (Scheme 2).

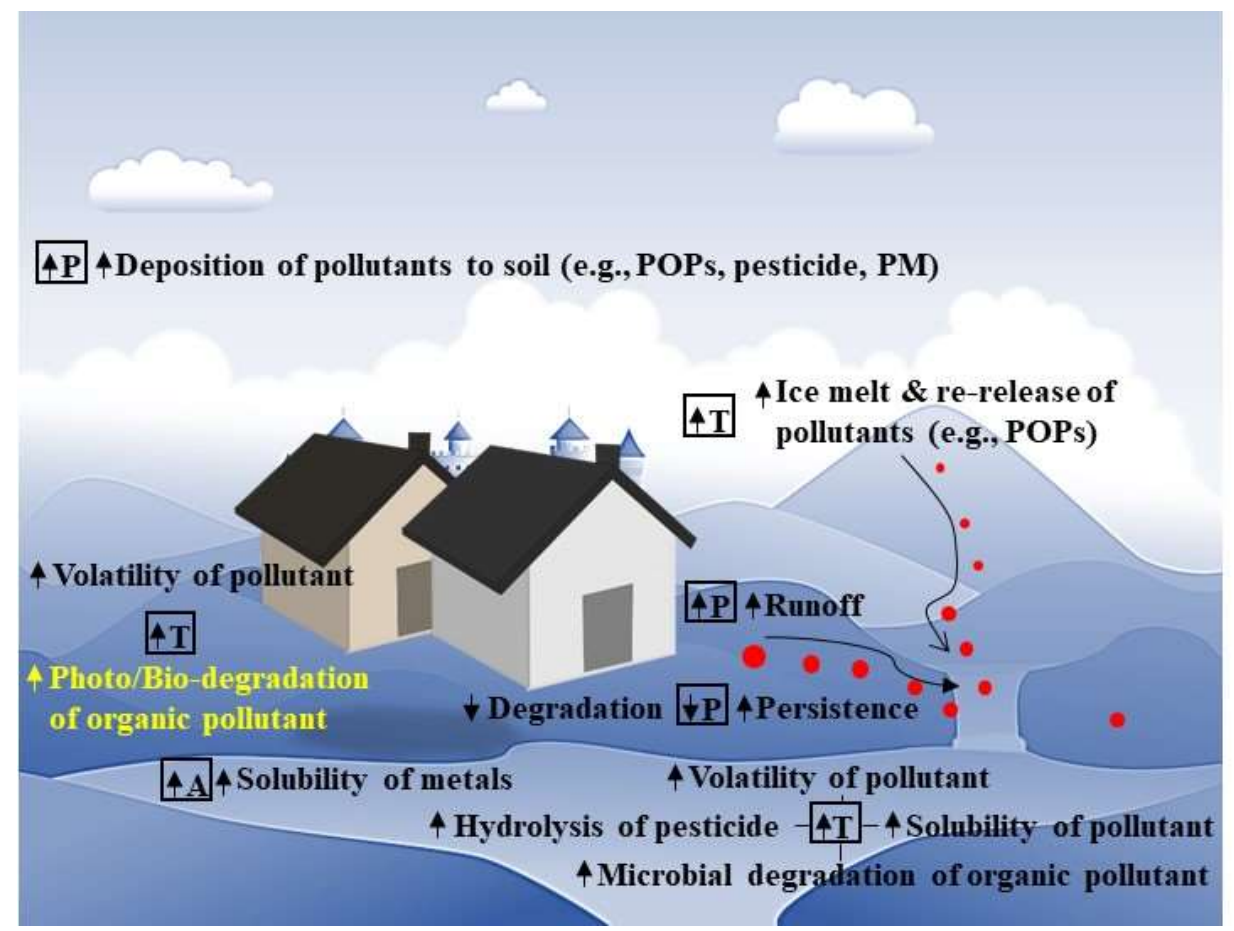

Scheme 2. Generalized view of the impact of extreme warming and precipitation on the dynamics of the chemical pollutants. The upside arrow $(\uparrow)$ indicates "increased" while downside arrow $(\downarrow)$ is for "decreased". $\mathrm{T}=$ temperature, $\mathrm{P}=$ precipitation, $\mathrm{A}=$ acidification, $\mathrm{POPs}=$ persistent organic pollutants, and $\mathrm{PM}=$ particulate matter. The content in the scheme is presented in detail and further instructed in the text. The scheme was modified after Noyes, et al. [20] with copyright permission of Elsevier Ltd.

Soil warming due to climate change has resulted in an increased transportation of contaminants in soils [60]. For example, simulating geomembrane assisted contaminant remediation in Arctic landfill resulted in elevated temperature $\left(+2{ }^{\circ} \mathrm{C}\right)$ in the soil surface and geomembranes increased the mobility of benzene, toluene, ethylbenzene, and xylene (BTEX) [61]. Also, higher soil surface and air temperatures, and faster wind speed enhanced the volatilization and dispersion of volatile organic and inorganic contaminants such as methane, ammonia, nitrous oxide, sulfides, and mercury from soils to air [43]. For example, the elevated temperature can increase the methylation rate of inorganic mercury in soil [62] and water and sediment [18,63]. In an anoxic environment, Yang et al. [62] reported that arctic soil temperature increased from $-2{ }^{\circ} \mathrm{C}$ to $+8{ }^{\circ} \mathrm{C}$ and favored the methylation of freshly added inorganic mercury by 10 -fold, mainly as a result of methanogenesis. In the case of elemental mercury $\left(\mathrm{Hg}^{0}\right)$, a $1{ }^{\circ} \mathrm{C}-3.7^{\circ} \mathrm{C}$ increase of surface soil warming in a climate change vulnerable region (Qinghai-Tibet Plateau permafrost) could increase the concentration of $\mathrm{Hg}^{0}$ by $9.4-40 \%$ in the surface soil $(0-5 \mathrm{~cm})$. The conversion from a less bioavailable form to a more bioavailable form of mercury is reported for mainly aquatic systems due to the increase of temperature $[43,63]$. However, due to the very limited evidence that exists of the bioavailable species of mercury in various soils, it is not known how the more bioavailable and toxic species of mercury (e.g., methylmercury) will affect humans. Using environmental biological receptors, the toxic effects of some other metal(loid)s have 
been reported [61]. For example, comparing two air temperatures $\left(20\right.$ and $\left.25^{\circ} \mathrm{C}\right)$ and using a drought simulation (50\% and 30\% moisture of water holding capacity of soil), González-Alcaraz and van Gestel [64] reported that in an extreme scenario $\left(30 \%\right.$ moisture but $25^{\circ} \mathrm{C}$ temperature) invertebrates in watercourse soil could accumulate more $\mathrm{Cd}, \mathrm{Pb}$, and $\mathrm{Zn}$ in their body and become severely damaged. In the Arctic, except for the above-mentioned changes of contaminant pathways, the temperature warming may shift ice/snow into water or trigger the thawing of previously permanently frozen soil layers and hence have immense consequences for physical and biological systems $[58,65,66]$. Such thawing/melting might trigger the exposure of previously frozen compounds in the arctic soils, alter hydrological flow paths, accelerate soil erosion and an increase in the surface runoff of contaminants [65]. In mining sites, downstream could also face an inflow of pollutants and increased temperature could accelerate this mobility. For example, temperature-induced snowmelt and its runoff carried a burden of $\mathrm{Zn}, \mathrm{SO}_{4}$, and $\mathrm{Mn}$ to the riven basis from the adjacent mining sites in the Colorado's rocky mountain areas [67]. In the case of organic contaminants, the volatilization could increase biotransformation, photodegradation, and biodegradation so that their removal or degradation occurs more favorably than transportation by surface runoff $[20,43,58-60,68,69]$. Some pesticides could also cause a higher level of oxidative stress to the soil organisms (e.g., earthworms) while they are exposed to the elevated ambient temperature $\left(25^{\circ} \mathrm{C}\right.$ compared to $\left.20^{\circ} \mathrm{C}\right)[70]$.

Precipitation also strongly affects the transfer of contaminants in soils [45]. In areas affected by climate change, the annual precipitation may decrease [42], increase [43,59] or extremely fluctuate depending on the latitude and regional atmospheric circulation pattern [71]. For example, with a climatic condition of increased precipitation, the concentration of perfluorooctanesulfonic compound (PFOS) was projected to be lower in urban soil and freshwater due to the surface runoff flow towards the rural soil and coastal habitat [45]. In some cases, increased flooding caused by climate change (e.g., rain surge) may lead to the mobilization of toxic chemicals (e.g., pesticide) stored in the soil or the remobilization of chemicals adsorbed on the soils [17]. For example, $\mathrm{Pb}$ and $\mathrm{Cd}$ appeared in soils of floodplains after the flooding of the river Meuse during the winter of 1993-1994 [17]. Increased soil moisture can increase the exposure, accumulation and ecotoxicity of inorganic mercury (e.g., $\mathrm{Hg}(\mathrm{II}))$ [72] in soils when they have been impacted by mercury deposition from the air. Submergence by flooding or rising sea level leads to oxygen deprivation and reducing conditions in soils (low redox potential, Eh) $[37,41,43]$. This affects the speciation, degradation, mobility, transport and cycling of various contaminants [37,43]. Arsenic methylation can occur in flood-affected anaerobic soils [73]. Another compelling example is that the reducing condition in coastal soils caused by sea or river water inundations induces a reductive dissolution of geogenic As-bearing mineral oxides and thereby releases As [37].

On the other hand, surface runoff and erosion, caused by the increased intensity and frequency of rainfall, storms or flooding, can increase the transportation of contaminants outside the parental soils. Dioxins, heavy metal(loid)s, cyanide, hydrophobic organics, ammonium, and hydrocarbons, from contaminated soils can be transported in a runoff to uncontaminated water and soil [40-43]. Intense rainfall events enhance the transfer of agrochemicals particularly from arable land to aquatic ecosystems with surface runoff and erosion [42]. On the other hand, soil tilling and crop harvesting can cause the release of soil particle-bound contaminants like steroids, pesticides, and polycyclic aromatic hydrocarbons from soils to air [74]. The hotter and drier summers as a result of climate change can worsen the contaminant release during these processes. At mining sites, more contaminant runoff or interruption of mining activities can occur following a possible disruption of the hydraulic structures like dams, ditches, spillways and holding ponds during heavy rainfall and flooding events under climate change scenarios [69].

\subsection{Soil Organic Carbon}

Climate change can alter organic carbon cycling and SOC dynamics in soils, leading to changes in the bioavailability of contaminants that are bound to SOC [66]. Increased soil temperature can 
accelerate the biological degradation of SOC, leaching, and surface runoff of DOC from soils, resulting in decreases in both SOC and DOC concentration in agricultural systems $[38,43,60,75]$. The released SOC-bound contaminants after erosion and contaminants bound to DOC in suspended particles in runoff increase accession of soil contaminants to water bodies [43,75]. Organic matter degradation showed little temperature sensitivity in a highly weathered clay-rich mature tropical forest soil due to the chemical protection of $C$ by mineral surfaces, whereas a higher temperature sensitivity would be expected for the SOM in a freshly tilled temperate prairie soil [52]. Studies by Giardina and Ryan [76] also demonstrated that SOC decomposition rates in mineral forest soils were not dependent on temperature alone. Similarly, Melillo et al. [77] showed that the acceleration of organic matter decomposition by soil warming is limited and short-lived for mid-latitude forests, which was attributed to the small labile SOC pool. Hence, global warming may increase SOC-bound contaminant release from some soils, but this is not necessarily the case for all soils, especially mineral soils.

\subsubsection{SOC for the Exposure of Organic Contaminants}

Increasing concentrations of organic matter in soil reduce the toxicity of some contaminants as they interact and diffuse into the organic matter [78,79]. Semple et al. [78] proposed that the bioavailability and extractability of hydrophobic organic contaminants can be represented by four fractions: (i) readily available, (ii) degradable and removal fraction, (iii) recalcitrant, and (iv) non-extractable fraction (Figure 2). Certain factors manipulate those fractions. For instance, organic matter and soil texture influence how much of a contaminant would be readily available or lost from the soil system over time. Similarly, microbial composition and abundance in soils and the oxidative and catalytic status (e.g., light intensity and soil enzyme) could determine the extent of removal and degradation of the readily available fraction of contaminants. As proposed in Figure 2, some consequences of climate change such as the alteration of SOC and microbial composition have governing roles in the model proposed by Semple et al. [78]. For example, in the global warming scenario, a sequestered portion of contaminants may become labile or the labile portion becomes more readily bioavailable [80]. A rise in temperature, generally, increases the toxicity of organic contaminants and is likely to enhance the rates of chemical and photodegradation [20] by increased light intensity. The oxidized but partially degraded final product could be more toxic than the original substrate [81].

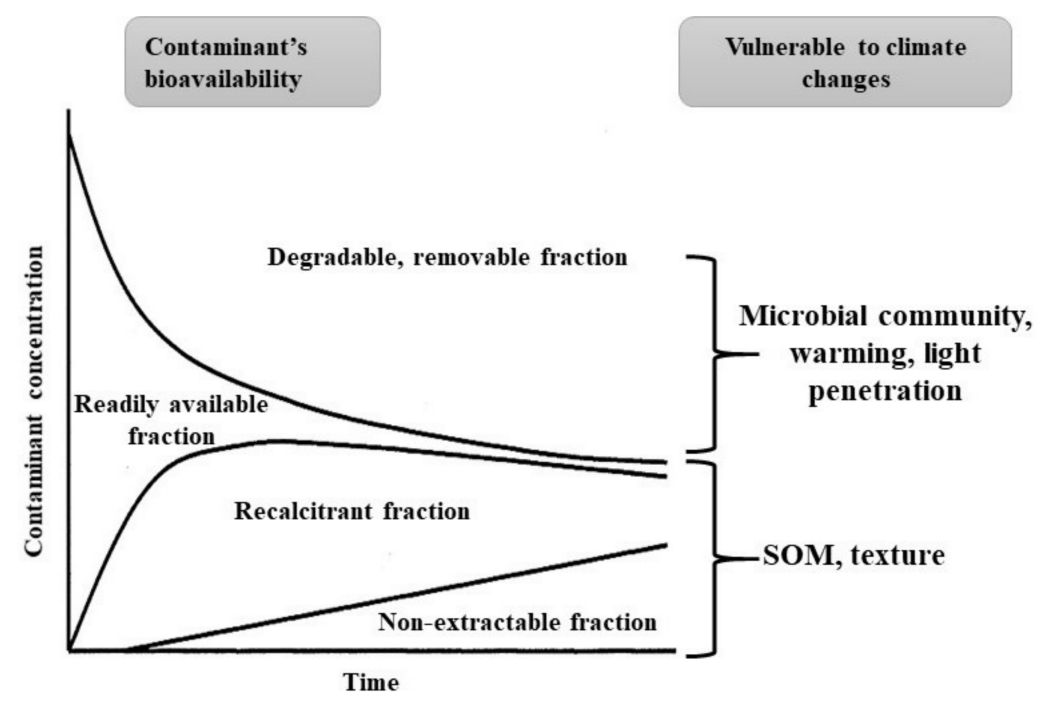

Figure 2. Various states of hydrophobic organic contaminant's bioavailability and extractability and the responsible soil properties that are vulnerable to climate changes. The figure is modified after Semple, et al. [78]. For the explanation of each line graph, see the text in Section 4.2.1. 


\subsubsection{SOC and Release of Metal(loid)s}

The availability and mobility of heavy metals depend on their adsorption and desorption in soils [82], which are strongly related to SOM (see Section 2). SOM affects the bioavailability and retention of heavy metals (e.g., $\mathrm{Cd}, \mathrm{Pb}, \mathrm{Cu}, \mathrm{Ni}$ and $\mathrm{Zn}$ ) in an exchangeable or complex form [83]. SOM acts either as a source of organic chemicals to the pore water or as a sink, strongly binding with heavy metals [84-87].

Warming and $\mathrm{CO}_{2}$ : As discussed in Section 3, increased temperature [88] and $\mathrm{CO}_{2}$ enrichment [89] both exert almost equipotential influence on organic carbon contents in soil, but in opposite directions. Thus globally, in warmer areas where increased atmospheric $\mathrm{CO}_{2}$ concentration is dominating, SOC content is expected to increase, whereas decreased SOC content may be observed in cooler regions where the effect from an increased temperature dominates [90]. Therefore, changes in soil temperature may affect the behavior of metal(loid), such as the adsorption-desorption process in soil, indirectly through their impacts on SOM [91,92]. Such changes in SOM have been reported to be responsible for a higher load of heavy metal (e.g., total $\mathrm{Hg}$ ) in soil subjected to $\mathrm{CO}_{2}$ enrichment [93]. It is generally agreed that the decomposition of SOM due to the increased temperature could reduce cation exchange capacity and therefore the soil lost capacity to retain heavy metal (research reviewed by Rajkumar et al. [94]). In other words, biological receptors, such as plant, could uptake more heavy metals of these available fractions in soil solution [94]; the insights are discussed in Section 4.5. Other variable soil properties such as $\mathrm{pH}$ and ionic strength relative to climate changes [55] could influence the extent of reaction between organic matter (e.g., humic acids) and metal ions and also the stability constant of metal-humic complexes [95].

Soil erosion: Climate change-induced soil erosion would increase the loss of surface soil that contains significantly greater amounts of SOM than deeper layers. Some scenarios predict a greater frequency and intensity of storms, which will have significant impacts on soil erosion [96]. This could lead to a significant loss of surface soil in any single year, 70-300 $\mathrm{t} \mathrm{ha}^{-1}$ in comparison with typical losses of 60-80 tha ${ }^{-1}$ (bare fallow), $8 \mathrm{t} \mathrm{ha}^{-1}$ (under a crop) and $0.24 \mathrm{t} \mathrm{ha}^{-1}$ (under pasture) [97]. This could lead the transport and migration of pollutants bound to SOC at transboundary scale and thus has become a great concern for human health [98-100]. In addition to its effect on SOM, soil erosion results in losses of the finer mineral fractions from the surface soil so that the suspended sediment has a greater sorption capacity for metals than the original soil (see Section 4.4.1 below).

\subsection{Soil Nitrogen and Phosphorus}

There is compelling evidence on the effect of chemical pollutants (e.g., heavy metals) on the $\mathrm{N}$ and $\mathrm{P}$ cycle due mainly to the interruption of microbial functions in these processes by those pollutants [101-103]. However, the coinciding phenomena has rarely been addressed. Considering key climate change effects, such as increased temperature, precipitation, and soil erosion, the soil runoff that contains $\mathrm{N}$ and $\mathrm{P}$ nutrients can cause eutrophication in lakes and coastal waters [104].

In a long-term study (May 2004 to April 2005) in the Mediterranean shrubland, Sardans et al. [13] reported a decrease of soil enzyme activities, such as urease, protease and $\beta$-glucosidase, which might further manipulate $\mathrm{N}$ cycle in soil. For example, applying artificial soil warming, these researchers argued that a $\sim 5^{\circ} \mathrm{C}$ to $1{ }^{\circ} \mathrm{C}$ increase of soil temperature might result in an excess amount of $\mathrm{NO}_{3}{ }^{-}$, but a low amount of $\mathrm{NH}_{4}{ }^{+}$species. Drought imposed a similar interference in the soil enzymes but the net loss/gain of $\mathrm{N}$ in the soil was not concluded [13]. On the other hand, the soil deposition of the atmospheric $\mathrm{NO}_{x}$ and $\mathrm{N}_{2} \mathrm{O}$ can change soil processes such as leaching, acidification, mineralization of organic matter, and nitrification rates [105]. It is not known whether the nitrogen stock and the speciation of nitrogen in soil have a direct effect on the mobility contaminants. However, the process related to $\mathrm{N}$ has a direct effect on the $\mathrm{N}$ accumulation on plants [13]. Nitrogen addition caused increased growth and dominance of some grass types and has been linked to increased rates of soil acidification and a loss of species diversity [106-108]. These two changes with soil $\mathrm{pH}$ and loss of biodiversity impact the mobility of heavy metals and the biologically mediated degradation or 
transformation of chemical pollutants. For example, in a study of a Dutch forest, van Breemen and van Dijk [109] reported that excess deposition of atmospheric $\mathrm{N}$ might cause soil acidification and therefore some pollutants (e.g., $\mathrm{Al}^{3+}$ ) could become more available to the biological receptors living in soil. Further on, the fate of soil biological processes and contaminants is discussed in Section 4.5.

Extreme climatic conditions could increase P runoff from land erosion in soil. For example, the higher precipitation and lower temperature in winter in northern temperate coastal regions led to a 3.3-16.5\% higher amount of P runoff [110]. Apart from the nutrient pollution of such runoff [104], the fate of pollutants present at the point of soil erosion can also be influenced. For example, in soils contaminated with a high concentration of heavy metal(loid) ions, the presence of $\mathrm{HPO}_{4}{ }^{2-}$ along with other anions such as $\mathrm{SO}_{4}{ }^{2-}, \mathrm{CO}_{3}{ }^{2-}$ and $\mathrm{OH}^{-}$cause the immobilization of metal(loid)s [111-113]. McGowen et al. [114] observed a decrease in the leaching of $\mathrm{Cd}, \mathrm{Pb}$, and $\mathrm{Zn}$ due to the formation of metal(loid)-P precipitates. However, in the P-limiting condition in agricultural soil (e.g., paddy soil), iron plaque is formed, which immobilizes heavy metals (e.g., Cd) [115]. In the case of temperature-induced soil acidification, this metal-binding complex is affected and thus a greater amount of metals becomes available to the plant-root system [116]; it further influences the plant accumulation of metals, such as the translocation of metals from root to shoot and disperses them into the shoot systems.

\subsection{Soil Minerals and the Exposure of Chemical Pollutants}

\subsubsection{Clay Minerals}

Clay minerals are naturally occurring phyllosilicate found in soil, sediments, and rocks. The history of clay mineralogy in soil is several decades old and still prospective in earth science [117]. The clay minerals in soil are complex and dependent on the weathering process in specific types of geological status; however, commonly occurring or exploring clay minerals in soils are mica, illite, smectite, kaolinite, etc. Descriptions of the structure and properties of clay minerals and their modified products can be found elsewhere [118,119].

There is no conclusive evidence that climate change directly impacts soil clay minerals. However, their fine particle size and associated organic matter strongly influence the bioavailability, and transport of pollutants $[35,120]$. In particular, organo-clay complexes in soil respond to soil warming and the release of bound heavy metals that may become available in soil [121,122].

Increased soil erosion caused by climate changes [123] causes the loss of clay from the surface of agricultural soils [124] and affects the transport of chemical contaminants bound to clay fractions [125]. Extreme rainfall and other means of erosion can also leach out dissolved salts from the soil surfaces that further destabilize the soil due to the lack of conductivity, leading to a loss of clays from the soil structure through the dispersion of clay particles. The mobility of contaminants is subjected to such destabilization of soil [41]. Clay minerals suspended in runoff could increase the adsorption of pollutants from solution to the solid phase. On the other hand, emerging research has shown the potential synergistic interaction between bacteria and clay minerals [126] for the enhanced bacteria-modulated biodegradation of organic pollutants such as PAHs [35,127-130], and pesticides [35,131].

Another aspect of the effects of climate change is the photodegradation of organic pollutants due to the direct effects of soil warming and light intensity [81,132]. The authors argued that partial degradation creates toxic intermediate metabolites in soils. In this instance, the photodegradation changes were affected by the texture of soil-the more clay minerals in soils the more degradation of PAH and atrazine [81,132]. However on balance, the benefits of clay minerals in the rhizosphere [133], for the stabilization of enzymes [134] and carbon in soils [135], might outweigh any detrimental effects in the challenge of increased radiation at the soil surface resulting from climate change. 


\subsubsection{Non-Clay Minerals}

In addition to clay minerals, other minerals such as feldspar, carbonates, micas, iron oxides, sulfides and chlorites [136] influence the behavior of contaminants. Under increased $\mathrm{CO}_{2}$ and temperature conditions, weathering and dissolution of these minerals might be the key process to consider $[137,138]$ and hence the sorption and mobility of contaminants in soil. However, direct evidence is rare in the available literature whether these climate change factors are governing the fate of such contaminants; rather, $\mathrm{pH}$-mediated contaminant mobility can occur. As discussed in Section 3, the soil minerals help buffer $\mathrm{pH}$ in soil. However, under elevated soil temperature, the availability of some minerals drops or raises soil $\mathrm{pH}$. For example, dissolution of pyrite, arsenopyrite and marcasite could generate acidity in soil and thus release mineral-bound heavy metal(loid)s into the soil solution $[40,69]$. On the other hand, the presence of other minerals such as calcite, dolomite, and limestone, dissolution of native and rock dust gypsum or weathering of aluminosilicate minerals can lead to higher $\mathrm{pH}$ that favors the precipitation of oxides and hydroxy sulfates and binds metals from solution [69].

Another important impact of climate change on soil non-clay minerals relates to flood immersion or rising sea levels that alter soil hydrological regimes featured by oxygen deprivation and also lower redox potential (Eh) [37]. Under submerged conditions, the reductive dissolution of As-bearing Fe- and Mn(hydro)- oxides may occur due to oxygen deprivation [37]. This dissolution caused elevated levels of arsenic from geogenic and anthropogenic sources along many coasts around the world, including south and southeast Asia and the United States [37]. However, when high $\mathrm{SO}_{4}{ }^{2-}$ is present under such anoxic conditions, metals can be immobilized as insoluble sulfides through their surface complexation. This reduction reaction of sulfate inhibited the dissolution of metal-bearing Fe oxides [37]. Flooding and the drying cycle of soils leads to fluctuating soil redox conditions, exerting direct or indirect influence on trace metal dynamics through changing soil $\mathrm{pH}, \mathrm{DOC}$, and the chemistry of Fe, Mn, and S minerals [139]. The redox cycling of trace metals and/or their host minerals determine the immobilization of these inorganic contaminants [140]. When the flooded soils are dried, the oxidation of reduced solute and solid-phase species occurs. A particular case is extreme soil acidification caused by pyrite oxidization when flooding recedes or sea level drops. Such soil acidification may release a range of contaminants including soil adsorbed $\mathrm{NH}_{4}{ }^{+}, \mathrm{Al}$ from clays, and other metal(loid)s such as $\mathrm{As}, \mathrm{Co}, \mathrm{Fe}, \mathrm{Mn}, \mathrm{Ni}$, and $\mathrm{Zn}$ from pyrite [141].

\subsection{Soil (Micro)organisms, Enzymes, and Plant Receptors}

Soil microorganisms and enzymes play pivotal roles in the decomposition of organic matter, nutrient cycling, energy flow, improvements in soil physicochemical qualities as well as pollutants' transformation [47]. The ecosystem services provided by the microbial community in soils are greatly influenced by climate drivers due to the fact that the growth and functions of microorganisms are largely driven by soil temperature and moisture [142,143]. In fact, a projected soil warming by $+4{ }^{\circ} \mathrm{C}$ in temperate forest could significantly increase (34-37\%) soil respiration in whole-soil (0-100 cm depth) due to the decomposition of decadal-aged carbon [144]. With such insights of the decomposition of mineral-associated SOC in the subsoil, it will be an interesting future study to understand the fate (e.g., degradation and re-immobilization) of adsorbed pollutants using the in situ depth-gradient approach. Under climate change, $\mathrm{CO}_{2}$ enrichment is also thought to have positive effects on plant productivity and growth, and in reducing heavy metal(loid) accumulation and increasing phytoremediation $[145,146]$. The increased photosynthesis and photosynthate allocation to the root system might increase root exudation and so enhance the bioavailability of contaminants to plants [147]. Root exudates act as ecological drivers for the microorganisms by supplying them with carbon and energy, and enhancing hydrocarbon degradation in the rhizosphere [148]. As a result, a distinct contaminant distribution gradient develops opposite to the gradient of root exudates, with the least contaminant concentration and the highest exudate concentration close to the roots [149]. The main role of root exudates in petroleum hydrocarbon degradation is a provision of energy 
and nutrients for microbial growth and activity [150]. A recent review by Hussain et al. [151] demonstrated that the remediation of total petroleum hydrocarbons (TPH) is effective with the synergies of phytoremediation and bioremediation (collectively called "rhizoremediation"). However, concern emerges with convincing evidence that soil warming and excess $\mathrm{N}$ input to soil impose stresses on the rhizobial microbial community [152]. In particular, changes in arbuscular mycorrhizal fungi (AMF) have been reported in several crop systems and the damage to AMF communities could reduce plants' capacity to resist chemical pollutants. In addition, increased atmospheric $\mathrm{CO}_{2}$ concentration may increase soil acidity by an increased input of carbonic acid released from root and microbial respiration [153,154]. Decreased pH decreases the adsorption of trace metals onto organic matter and metal oxides [91], thereby increasing their bioavailability and uptake by plants [155,156]. This may result in higher bioavailability of pollutants to humans and other animals that consume affected plants [157].

In an in situ experiment using a thermal gradient of $4-40{ }^{\circ} \mathrm{C}$ in Antarctica, the Arctic, and the tropics [158] reported that the relative activity of fungal hydrolase enzyme increased with rising temperature in the soils in polar regions. This indicates the potential for warming climates to lead to more decomposition of organic molecules in the soil, which is related to the bioavailability of chemical pollutants in those regions. However, the reverse consequence can also occur if released heavy metals are toxic. In other words, the interactive effects of heavy metals and soil warming might have negative impacts on the microbial enzymatic functions [159]. In various contrasting soils, Tan, et al. [159] reported that higher temperatures, especially in alkaline soils, might cause damage to the alkaline phosphatase activity of soil microorganism. The mechanisms underpinning such damage could be the temperature-induced $\mathrm{Cd}$ availability that posed an inhibitory effect on microorganisms [159]. Sardans et al. [160] noticed an increased As solubility $(67 \%)$ and decreased total As (21\%) in soil while soil warming was recorded as a $0.95^{\circ} \mathrm{C}$ increment at $-5 \mathrm{~cm}$ soil depth. The higher phosphatase activity in such warming soil releases a greater amount of soluble phosphorous, and the anion exchange of arsenate by phosphate increases soil soluble As, hence an available element for the plant's uptake [160].

However, the overall effects of climate change on the bioavailability of contaminants depends on the interactions between contaminants, soil factors, and environmental receptors. For example, during an eight year warming and drought manipulation of a Mediterranean shrubland, drought increased total $\mathrm{Hg}$ concentrations by $350 \%$ in soils but had no significant effects on trace element accumulation in aboveground biomass [160]. Sardans et al. [160] showed increased bioavailability of heavy metals due to changing environments and soil properties. The authors found that warming increased aboveground accumulation of $\mathrm{Al}, \mathrm{As}, \mathrm{Cr}, \mathrm{Cu}$, and partially $\mathrm{Pb}$ by plant root uptake, and this increase varied with plant types. Drought increased As (40\%) and Cd (55\%) in Elaeagnus multiflora stems, whereas it decreased $\mathrm{Cu}(50 \%)$ in leaves, $\mathrm{Ni}(28 \%)$ in stems and $\mathrm{Pb}(32 \%)$ in leaf litter of Globularia alypum [160].

\section{Conclusions, Challenges, and the Way Forward}

In summary, major mechanisms by which climate change influences soil contaminant processes are the changes in contaminant exposure and alteration of transport pathways related to changes in precipitation, including surface runoff, precipitation, evaporation, and degradation. The other primary pathway was that climate change induces changes of soil conditions such as soil temperature, soil moisture, $\mathrm{pH}$ and redox potential, SOC, nitrogen and phosphorus, soil minerals and alter contaminant's binding/releasing, oxidation/reduction and species of contaminants. This review summarized several of such processes that are affected by climate changes (Table 1). 
Table 1. Summary of climate change drivers on soil properties and processes and toxicological aspects of chemical pollutants.

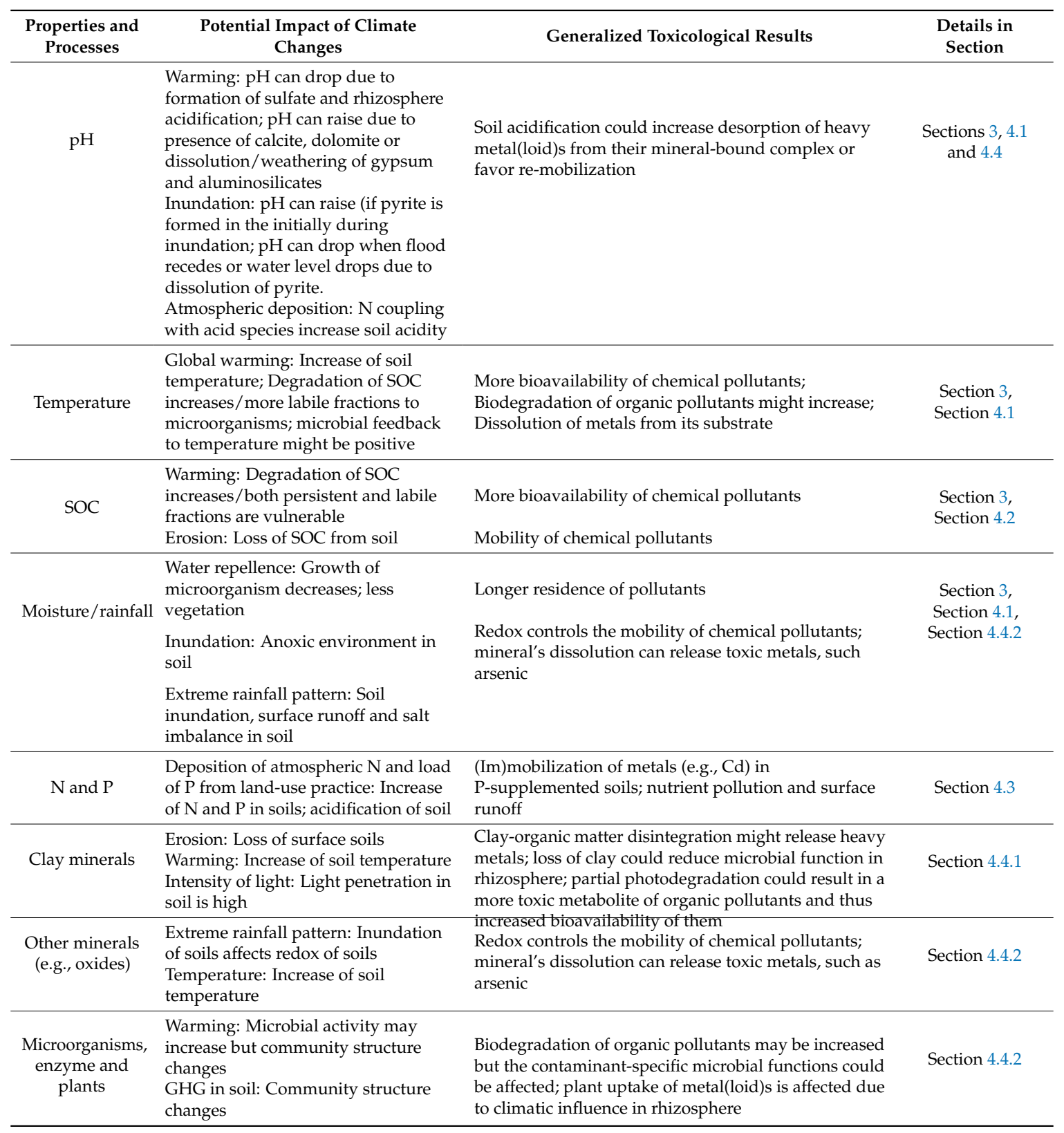

Overall, humanity's exposure to contaminants could be increased due to climate change. The key mechanisms for this risk may be the desorption and remobilization of soil contaminants. However, reaching a conclusion on whether climate changes have any direct effects on the magnitude of chemical toxicity is difficult due to the limited availability of studies. The extent of identified pathway depends on both the state and properties of contaminants; these includes the solubility, hydrophobicity and volatility of the contaminants. From toxicological perspective of soil contaminants, one important factor is the speciation of contaminants. This review finds limited evidence that few species of contaminants, such as methylation of mercury and arsenic or metabolites of polycyclic aromatic hydrocarbons or pesticides, might increase the toxicity risk for humans. This aspect should be studied and priority contaminants identified. The microbial feedback to climate change could be another key aspect that should be counted in relation to the fate of chemical pollutants and the exposure of them and their metabolites to humans. Although our charge in this study is not to review the molecular details of 
the potential change in the microbial community structure due to climate change, we observed that microbial feedback to the addition of greenhouse gases in soil is the alteration of their community. Hence, further research should be directed at how these changes at the molecular level influence the microbial-assisted transformation and degradation of pollutants at the short-and long-term scale. The knowledge summarized by this review and future insight can pave our way to addressing the connections between the two critical planetary boundaries that are 'climate change' and 'chemical pollutants'.

Author Contributions: B.B. conceived the concept, wrote major parts, revised contents. All authors listed in the author list drafted and reviewed various sections. R.N. is the sole senior author.

Funding: This research was funded by Cooperative Centre for Contamination Assessment and Remediation of the Environment (CRC CARE) grant number [care 6.47.01].

Acknowledgments: All authors thank anonymous reviewers for their careful reading and valuable comments to improve our manuscript. B.B. acknowledges CRC CARE for general financial and University of South Australia for other logistical support for this study.

Conflicts of Interest: The authors declare no conflict of interest.

\section{References}

1. Landis, W.G.; Yu, M.-H. Introduction to Environmental Toxicology-Impacts of Chemicals upon Ecological Systems; CRC Press: Boca Raton, FL, USA, 2004; p. 484.

2. Landrigan, P.J.; Schechter, C.B.; Lipton, J.M.; Fahs, M.C.; Schwartz, J. Environmental pollutants and disease in American children: Estimates of morbidity, mortality, and costs for lead poisoning, asthma, cancer, and developmental disabilities. Environ. Health Perspect. 2002, 110, 721-728. [CrossRef] [PubMed]

3. Grandjean, P.; Landrigan, P.J. Neurobehavioural effects of developmental toxicity. Lancet Neurol. 2014, 13, 330-338. [CrossRef]

4. Konkel, L. Compound interest: Assessing the effects of chemical mixtures. Environ. Health Perspect. 2017, 125. [CrossRef] [PubMed]

5. National Research Council. Basic Research Opportunities in Earth Science; National Academies Press: Washington, DC, USA, 2001.

6. Banwart, S.A.; Bernasconi, S.M.; Blum, W.E.H.; de Souza, D.M.; Chabaux, F.; Duffy, C.; Kercheva, M.; Krám, P.; Lair, G.J.; Lundin, L.; et al. Soil functions in earth's critical zone: Key results and conclusions. In Advances in Agronomy; Banwart, S.A., Sparks, D.L., Eds.; Academic Press: Burlington, VT, USA, 2017; Volume 142, pp. 1-27.

7. Richter, D.D.; Mobley, M.L. Monitoring earth's critical zone. Science 2009, 326, 1067-1068. [CrossRef] [PubMed]

8. Rockström, J.; Steffen, W.; Noone, K.; Persson, Å.; Chapin, F.S., III; Lambin, E.F.; Lenton, T.M.; Scheffer, M.; Folke, C.; Schellnhuber, H.J.; et al. A safe operating space for humanity. Nature 2009, 461, 472. [CrossRef] [PubMed]

9. Bouskill, N.J.; Wood, T.E.; Baran, R.; Ye, Z.; Bowen, B.P.; Lim, H.; Zhou, J.; Nostrand, J.D.V.; Nico, P.; Northen, T.R.; et al. Belowground response to drought in a tropical forest soil. I. Changes in microbial functional potential and metabolism. Front. Microbiol. 2016, 7, 525. [CrossRef] [PubMed]

10. Smith, P. Soils and climate change. Curr. Opin. Environ. Sustain. 2012, 4, 539-544. [CrossRef]

11. Garcia-Pichel, F.; Loza, V.; Marusenko, Y.; Mateo, P.; Potrafka, R.M. Temperature drives the continental-scale distribution of key microbes in topsoil communities. Science 2013, 340, 1574-1577. [CrossRef] [PubMed]

12. Bellard, C.; Bertelsmeier, C.; Leadley, P.; Thuiller, W.; Courchamp, F. Impacts of climate change on the future of biodiversity. Ecol. Lett. 2012, 15, 365-377. [CrossRef] [PubMed]

13. Sardans, J.; Peñuelas, J.; Estiarte, M. Changes in soil enzymes related to $\mathrm{C}$ and $\mathrm{N}$ cycle and in soil $\mathrm{C}$ and $\mathrm{N}$ content under prolonged warming and drought in a mediterranean shrubland. Appl. Soil Ecol. 2008, 39, 223-235. [CrossRef]

14. Classen, A.T.; Sundqvist, M.K.; Henning, J.A.; Newman, G.S.; Moore, J.A.M.; Cregger, M.A.; Moorhead, L.C.; Patterson, C.M. Direct and indirect effects of climate change on soil microbial and soil microbial-plant interactions: What lies ahead? Ecosphere 2015, 6, 1-21. [CrossRef] 
15. Li, Z.; Liu, W.-Z.; Zhang, X.-C.; Zheng, F.-L. Assessing the site-specific impacts of climate change on hydrology, soil erosion and crop yields in the loess plateau of China. Clim. Chang. 2011, 105, $223-242$. [CrossRef]

16. Davidson, E.A.; Trumbore, S.E.; Amundson, R. Soil warming and organic carbon content. Nature 2000, 408, 789. [CrossRef] [PubMed]

17. Haines, A.; Kovats, R.S.; Campbell-Lendrum, D.; Corvalan, C. Climate change and human health: Impacts, vulnerability and public health. Public Health 2006, 120, 585-596. [CrossRef] [PubMed]

18. Alava, J.J.; Cheung, W.W.L.; Ross, P.S.; Sumaila, U.R. Climate change-contaminant interactions in marine food webs: Toward a conceptual framework. Glob. Chang. Biol. 2017, 23, 3984-4001. [CrossRef] [PubMed]

19. Lipczynska-Kochany, E. Effect of climate change on humic substances and associated impacts on the quality of surface water and groundwater: A review. Sci. Total Environ. 2018, 640, 1548-1565. [CrossRef] [PubMed]

20. Noyes, P.D.; McElwee, M.K.; Miller, H.D.; Clark, B.W.; Van Tiem, L.A.; Walcott, K.C.; Erwin, K.N.; Levin, E.D. The toxicology of climate change: Environmental contaminants in a warming world. Environ. Int. 2009, 35, 971-986. [CrossRef] [PubMed]

21. ATSDR. Agency for Toxic Substances and Disease Registry; Department of Health and Human Services: Atlanta, GA, USA, 2017.

22. Naidu, R.; Bolan, N.S.; Megharaj, M.; Juhasz, A.L.; Gupta, S.K.; Clothier, B.E.; Schulin, R. Chemical bioavailability in terrestrial environments. In Developments in Soil Science; Hartemink, A.E., McBratney, A.B., Naidu, R., Eds.; Elsevier: Amsterdam, The Netherlands, 2008; Volume 32, pp. 1-6.

23. Poggio, L.; Vrščaj, B.; Schulin, R.; Hepperle, E.; Ajmone Marsan, F. Metals pollution and human bioaccessibility of topsoils in Grugliasco (Italy). Environ. Pollut. 2009, 157, 680-689. [CrossRef] [PubMed]

24. Khan, M.A.I.; Biswas, B.; Smith, E.; Mahmud, S.A.; Hasan, N.A.; Khan, M.A.W.; Naidu, R.; Megharaj, M. Microbial diversity changes with rhizosphere and hydrocarbons in contrasting soils. Ecotoxicol. Environ. Saf. 2018, 156, 434-442. [CrossRef] [PubMed]

25. Harter, R.D.; Naidu, R. Role of metal-organic complexation in metal sorption by soils. In Advances in Agronomy; Sparks, D.L., Ed.; Academic Press: Burlington, VT, USA, 1995; Volume 55, pp. 219-263.

26. Bolan, N.S.; Adriano, D.C.; Mani, P.A.; Duraisamy, A. Immobilization and phytoavailability of cadmium in variable charge soils. II. Effect of lime addition. Plant Soil 2003, 251, 187-198. [CrossRef]

27. Naidu, R.; Harter, R.D. Effect of different organic ligands on cadmium sorption by and extractability from soils. Soil Sci. Soc. Am. J. 1998, 62, 644-650. [CrossRef]

28. Hong, C.O.; Chung, D.Y.; Lee, D.K.; Kim, P.J. Comparison of phosphate materials for immobilizing cadmium in soil. Arch. Environ. Contam. Toxicol. 2010, 58, 268-274. [CrossRef] [PubMed]

29. Naidu, R.; Bolan, N.S.; Kookana, R.S.; Tiller, K.G. Ionic-strength and pH effects on the sorption of cadmium and the surface charge of soils. Eur. J. Soil Sci. 2006, 45, 419-429. [CrossRef]

30. Bianchi, S.R.; Miyazawa, M.; Oliveira, E.L.; Pavan, M.A. Relationship between the mass of organic matter and carbon in soil. Braz. Arch. Biol. Technol. 2008, 51, 263-269. [CrossRef]

31. Qi, F.; Kuppusamy, S.; Naidu, R.; Bolan, N.S.; Ok, Y.S.; Lamb, D.; Li, Y.; Yu, L.; Semple, K.T.; Wang, H. Pyrogenic carbon and its role in contaminant immobilization in soils. Crit. Rev. Environ. Sci. Technol. 2017, 47, 795-876. [CrossRef]

32. Brümmer, G.W. Heavy metal species, mobility and availability in soils. In The Importance of Chemical "Speciation" in Environmental Processes; Bernhard, M., Brinckman, F.E., Sadler, P.J., Eds.; Springer: Berlin/Heidelberg, Germany, 1984; pp. 169-192.

33. Siripinyanond, A.; Worapanyanond, S.; Shiowatana, J. Field-flow fractionation-inductively coupled plasma mass spectrometry: An alternative approach to investigate metal-humic substances interaction. Environ. Sci. Technol. 2005, 39, 3295-3301. [CrossRef] [PubMed]

34. Sparks, D.L. Chemistry of soil organic matter. In Environmental Soil Chemistry, 2nd ed.; Academic Press: Burlington, VT, USA, 2003; pp. 75-113.

35. Biswas, B.; Sarkar, B.; Rusmin, R.; Naidu, R. Bioremediation of PAHs and VOCs: Advances in clay mineral-microbial interaction. Environ. Int. 2015, 85, 168-181. [CrossRef] [PubMed]

36. Bolan, N.; Kunhikrishnan, A.; Thangarajan, R.; Kumpiene, J.; Park, J.; Makino, T.; Kirkham, M.B.; Scheckel, K. Remediation of heavy metal(loid)s contaminated soils-To mobilize or to immobilize? J. Hazard. Mater. 2014, 266, 141-166. [CrossRef] [PubMed] 
37. LeMonte, J.J.; Stuckey, J.W.; Sanchez, J.Z.; Tappero, R.; Rinklebe, J.; Sparks, D.L. Sea level rise induced arsenic release from historically contaminated coastal soils. Environ. Sci. Technol. 2017, 51, 5913-5922. [CrossRef] [PubMed]

38. Stergiadi, M.; van der Perk, M.; de Nijs, A.C.M.; Bierkens, M.F.P. Effects of climate change and land management on soil organic carbon dynamics and carbon leaching in Northwestern Europe. Biogeosci. Discuss. 2015, 12, 19627-19671. [CrossRef]

39. Vale, C.; Canário, J.; Caetano, M.; Poissant, L.; Ferreira, A.M. Contaminant cycling under climate change: Evidences and scenarios. In Oceans and the Atmospheric Carbon Content; Duarte, P., Santana-Casiano, J.M., Eds.; Springer Netherlands: Dordrecht, The Netherlands, 2011; pp. 133-156.

40. Anawar, H.M. Sustainable rehabilitation of mining waste and acid mine drainage using geochemistry, mine type, mineralogy, texture, ore extraction and climate knowledge. J. Environ. Manag. 2015, 158, 111-121. [CrossRef] [PubMed]

41. Jesus, J.M.; Danko, A.S.; Fiúza, A.; Borges, M.-T. Phytoremediation of salt-affected soils: A review of processes, applicability, and the impact of climate change. Environ. Sci. Pollut. Res. 2015, 22, 6511-6525. [CrossRef] [PubMed]

42. Serpa, D.; Nunes, J.P.; Keizer, J.J.; Abrantes, N. Impacts of climate and land use changes on the water quality of a small Mediterranean catchment with intensive viticulture. Environ. Pollut. 2017, 224, 454-465. [CrossRef] [PubMed]

43. Boxall, A.B.A.; Hardy, A.; Beulke, S.; Boucard, T.; Burgin, L.; Falloon, P.D.; Haygarth, P.M.; Hutchinson, T.; Kovats, R.S.; Leonardi, G.; et al. Impacts of climate change on indirect human exposure to pathogens and chemicals from agriculture. Environ. Health Perspect. 2009, 117, 508-514. [CrossRef] [PubMed]

44. Lake, I.R.; Hooper, L.; Abdelhamid, A.; Bentham, G.; Boxall, A.B.A.; Draper, A.; Fairweather-Tait, S.; Hulme, M.; Hunter, P.R.; Nichols, G.; et al. Climate change and food security: Health impacts in developed countries. Environ. Health Perspect. 2012, 120, 1520-1526. [CrossRef] [PubMed]

45. Su, C.; Song, S.; Lu, Y.; Liu, S.; Giesy, J.P.; Chen, D.; Jenkins, A.; Sweetman, A.J.; Yvette, B. Potential effects of changes in climate and emissions on distribution and fate of perfluorooctane sulfonate in the Bohai Rim, China. Sci. Total Environ. 2018, 613, 352-360. [CrossRef] [PubMed]

46. IPCC. Climate Change 2014: Synthesis Report. Contribution of Working Groups I, II and III to the Fifth Assessment Report of the Intergovernmental Panel on Climate Change; IPCC: Geneva, Switzerland, 2014; p. 151.

47. Srivastava, P.; Singh, R.; Tripathi, S.; Singh, P.; Singh, S.; Singh, H.; Raghubanshi, A.S.; Mishra, P.K. Soil carbon dynamics under changing climate-A research transition from absolute to relative roles of inorganic nitrogen pools and associated microbial processes: A review. Pedosphere 2017, 27, 792-806. [CrossRef]

48. Liu, X.; Zhang, Y.; Han, W.; Tang, A.; Shen, J.; Cui, Z.; Vitousek, P.; Erisman, J.W.; Goulding, K.; Christie, P.; et al. Enhanced nitrogen deposition over China. Nature 2013, 494, 459. [CrossRef] [PubMed]

49. Melillo, J.M.; Frey, S.D.; DeAngelis, K.M.; Werner, W.J.; Bernard, M.J.; Bowles, F.P.; Pold, G.; Knorr, M.A.; Grandy, A.S. Long-term pattern and magnitude of soil carbon feedback to the climate system in a warming world. Science 2017, 358, 101-105. [CrossRef] [PubMed]

50. Crowther, T.W.; Todd-Brown, K.E.O.; Rowe, C.W.; Wieder, W.R.; Carey, J.C.; Machmuller, M.B.; Snoek, B.L.; Fang, S.; Zhou, G.; Allison, S.D.; et al. Quantifying global soil carbon losses in response to warming. Nature 2016, 540, 104. [CrossRef] [PubMed]

51. Peng, C.; Zhou, X.; Zhao, S.; Wang, X.; Zhu, B.; Piao, S.; Fang, J. Quantifying the response of forest carbon balance to future climate change in Northeastern China: Model validation and prediction. Glob. Planet. Chang. 2009, 66, 179-194. [CrossRef]

52. Davidson, E.A.; Janssens, I.A. Temperature sensitivity of soil carbon decomposition and feedbacks to climate change. Nature 2006, 440, 165. [CrossRef] [PubMed]

53. Frank, D.; Reichstein, M.; Bahn, M.; Thonicke, K.; Frank, D.; Mahecha, M.D.; Smith, P.; Van der Velde, M.; Vicca, S.; Babst, F.; et al. Effects of climate extremes on the terrestrial carbon cycle: concepts, processes and potential future impacts. Glob. Chang. Biol. 2015, 21, 2861-2880. [CrossRef] [PubMed]

54. Pearce, F. Lakes of Acid. New Sci. 2018, 238, 38-41. [CrossRef]

55. Rengel, Z. Soil pH, soil health and climate change. In Soil Health and Climate Change; Singh, B.P., Cowie, A.L., Chan, K.Y., Eds.; Springer: Berlin/Heidelberg, Germany, 2011; pp. 69-85.

56. Zheng, S.; Bian, H.; Quan, Q.; Xu, L.; Chen, Z.; He, N. Effect of nitrogen and acid deposition on soil respiration in a temperate forest in China. Geoderma 2018, 329, 82-90. [CrossRef] 
57. Carré, F.; Caudeville, J.; Bonnard, R.; Bert, V.; Boucard, P.; Ramel, M. Soil contamination and human health: A major challenge for global soil security. In Global Soil Security; Field, D.J., Morgan, C.L.S., McBratney, A.B., Eds.; Springer International Publishing: Cham, Switzerland, 2017; pp. 275-295.

58. Macdonald, R.W.; Harner, T.; Fyfe, J. Recent climate change in the Arctic and its impact on contaminant pathways and interpretation of temporal trend data. Sci. Total Environ. 2005, 342, 5-86. [CrossRef] [PubMed]

59. Armitage, J.M.; Quinn, C.L.; Wania, F. Global climate change and contaminants-an overview of opportunities and priorities for modelling the potential implications for long-term human exposure to organic compounds in the Arctic. J. Environ. Monit. 2011, 13, 1532-1546. [CrossRef] [PubMed]

60. Strååt, K.D.; Mörth, C.-M.; Undeman, E. Future export of particulate and dissolved organic carbon from land to coastal zones of the Baltic Sea. J. Mar. Syst. 2018, 177, 8-20. [CrossRef]

61. McWatters, R.S.; Rutter, A.; Rowe, R.K. Geomembrane applications for controlling diffusive migration of petroleum hydrocarbons in cold region environments. J. Environ. Manag. 2016, 181, 80-94. [CrossRef] [PubMed]

62. Yang, Z.; Fang, W.; Lu, X.; Sheng, G.-P.; Graham, D.E.; Liang, L.; Wullschleger, S.D.; Gu, B. Warming increases methylmercury production in an Arctic soil. Environ. Pollut. 2016, 214, 504-509. [CrossRef] [PubMed]

63. Booth, S.; Zeller, D. Mercury, food webs, and marine mammals: Implications of diet and climate change for human health. Environ. Health Perspect. 2005, 113, 521-526. [CrossRef] [PubMed]

64. González-Alcaraz, M.N.; van Gestel, C.A.M. Climate change effects on enchytraeid performance in metal-polluted soils explained from changes in metal bioavailability and bioaccumulation. Environ. Res. 2015, 142, 177-184. [CrossRef] [PubMed]

65. Klaminder, J.; Hammarlund, D.; Kokfelt, U.; Vonk, J.E.; Bigler, C. Lead contamination of subarctic lakes and its response to reduced atmospheric fallout: Can the recovery process be counteracted by the ongoing climate change? Environ. Sci. Technol. 2010, 44, 2335-2340. [CrossRef] [PubMed]

66. Teran, T.; Lamon, L.; Marcomini, A. Climate change effects on POPs' environmental behaviour: A scientific perspective for future regulatory actions. Atmos. Pollut. Res. 2012, 3, 466-476. [CrossRef]

67. Todd, A.S.; Manning, A.H.; Verplanck, P.L.; Crouch, C.; McKnight, D.M.; Dunham, R. Climate-change-driven deterioration of water quality in a mineralized watershed. Environ. Sci. Technol. 2012, 46, 9324-9332. [CrossRef] [PubMed]

68. Bloomfield, J.P.; Williams, R.J.; Gooddy, D.C.; Cape, J.N.; Guha, P. Impacts of climate change on the fate and behaviour of pesticides in surface and groundwater-A UK perspective. Sci. Total Environ. 2006, 369, 163-177. [CrossRef] [PubMed]

69. Anawar, H.M. Impact of climate change on acid mine drainage generation and contaminant transport in water ecosystems of semi-arid and arid mining areas. Phys. Chem. Earth Parts A/B/C 2013, 58, 13-21. [CrossRef]

70. Velki, M.; Ečimović, S. Changes in exposure temperature lead to changes in pesticide toxicity to earthworms: A preliminary study. Environ. Toxicol. Pharmacol. 2015, 40, 774-784. [CrossRef] [PubMed]

71. Dore, M.H.I. Climate change and changes in global precipitation patterns: What do we know? Environ. Int. 2005, 31, 1167-1181. [CrossRef] [PubMed]

72. Buch, A.C.; Schmelz, R.M.; Niva, C.C.; Correia, M.E.F.; Silva-Filho, E.V. Mercury critical concentrations to Enchytraeus crypticus (Annelida: Oligochaeta) under normal and extreme conditions of moisture in tropical soils-Reproduction and survival. Environ. Res. 2017, 155, 365-372. [CrossRef] [PubMed]

73. Beesley, L.; Inneh, O.S.; Norton, G.J.; Moreno-Jimenez, E.; Pardo, T.; Clemente, R.; Dawson, J.J. Assessing the influence of compost and biochar amendments on the mobility and toxicity of metals and arsenic in a naturally contaminated mine soil. Environ. Pollut. 2014, 186, 195-202. [CrossRef] [PubMed]

74. Zobeck, T.M.; Van Pelt, R.S. Wind-induced dust generation and transport mechanics on a bare agricultural field. J. Hazard. Mater. 2006, 132, 26-38. [CrossRef] [PubMed]

75. Macdonald, R.W.; Mackay, D.; Li, Y.F.; Hickie, B. How will global climate change affect risks from long-range transport of persistent organic pollutants? Hum. Ecol. Risk Assess. Int. J. 2003, 9, 643-660. [CrossRef]

76. Giardina, C.P.; Ryan, M.G. Evidence that decomposition rates of organic carbon in mineral soil do not vary with temperature. Nature 2000, 404, 858. [CrossRef] [PubMed]

77. Melillo, J.M.; Steudler, P.A.; Aber, J.D.; Newkirk, K.; Lux, H.; Bowles, F.P.; Catricala, C.; Magill, A.; Ahrens, T.; Morrisseau, S. Soil warming and carbon-cycle feedbacks to the climate system. Science 2002, 298, 2173-2176. [CrossRef] [PubMed] 
78. Semple, K.T.; Morriss, A.W.J.; Paton, G.I. Bioavailability of hydrophobic organic contaminants in soils: Fundamental concepts and techniques for analysis. Eur. J. Soil Sci. 2003, 54, 809-818. [CrossRef]

79. Xing, B.; Pignatello, J.J. Dual-mode sorption of low-polarity compounds in glassy poly (vinyl chloride) and soil organic matter. Environ. Sci. Technol. 1997, 31, 792-799. [CrossRef]

80. Schiedek, D.; Sundelin, B.; Readman, J.W.; Macdonald, R.W. Interactions between climate change and contaminants. Mar. Pollut. Bull. 2007, 54, 1845-1856. [CrossRef] [PubMed]

81. Marquès, M.; Mari, M.; Audí-Miró, C.; Sierra, J.; Soler, A.; Nadal, M.; Domingo, J.L. Climate change impact on the PAH photodegradation in soils: Characterization and metabolites identification. Environ. Int. 2016, 89-90, 155-165. [CrossRef] [PubMed]

82. Wijayawardena, M.A.A.; Naidu, R.; Megharaj, M.; Lamb, D.; Thavamani, P.; Kuchel, T. Using soil properties to predict in vivo bioavailability of lead in soils. Chemosphere 2015, 138, 422-428. [CrossRef] [PubMed]

83. Zeng, F.; Ali, S.; Zhang, H.; Ouyang, Y.; Qiu, B.; Wu, F.; Zhang, G. The influence of pH and organic matter content in paddy soil on heavy metal availability and their uptake by rice plants. Environ. Pollut. 2011, 159, 84-91. [CrossRef] [PubMed]

84. Temminghoff, E.J.; Van der Zee, S.E.; de Haan, F.A. Copper mobility in a copper-contaminated sandy soil as affected by $\mathrm{pH}$ and solid and dissolved organic matter. Environ. Sci. Technol. 1997, 31, 1109-1115. [CrossRef]

85. Sauvé, S.; McBride, M.B.; Norvell, W.A.; Hendershot, W.H. Copper solubility and speciation of in situ contaminated soils: effects of copper level, pH and organic matter. Water Air Soil Pollut. 1997, 100, 133-149. [CrossRef]

86. Lamb, D.T.; Ming, H.; Megharaj, M.; Naidu, R. Heavy metal (Cu, Zn, Cd and Pb) partitioning and bioaccessibility in uncontaminated and long-term contaminated soils. J. Hazard. Mater. 2009, 171, 1150-1158. [CrossRef] [PubMed]

87. Christensen, J.B.; Jensen, D.L.; Christensen, T.H. Effect of dissolved organic carbon on the mobility of cadmium, nickel and zinc in leachate polluted groundwater. Water Res. 1996, 30, 3037-3049. [CrossRef]

88. Lewis, D.B.; Brown, J.A.; Jimenez, K.L. Effects of flooding and warming on soil organic matter mineralization in Avicennia germinans mangrove forests and Juncus roemerianus salt marshes. Estuar. Coast. Shelf Sci. 2014, 139, 11-19. [CrossRef]

89. Hofmockel, K.S.; Zak, D.R.; Moran, K.K.; Jastrow, J.D. Changes in forest soil organic matter pools after a decade of elevated $\mathrm{CO}_{2}$ and $\mathrm{O}_{3}$. Soil Biol. Biochem. 2011, 43, 1518-1527. [CrossRef]

90. Kirschbaum, M.U.F. Will changes in soil organic carbon act as a positive or negative feedback on global warming? Biogeochemistry 2000, 48, 21-51. [CrossRef]

91. Bradl, H.B. Adsorption of heavy metal ions on soils and soils constituents. J. Colloid Interface Sci. 2004, 277, 1-18. [CrossRef] [PubMed]

92. Kashem, M.; Singh, B. Metal availability in contaminated soils: I. Effects of floodingand organic matter on changes in Eh, Ph and solubility of Cd, Ni and Zn. Nutr. Cycl. Agroecosyst. 2001, 61, 247-255. [CrossRef]

93. Natali, S.M.; Sañudo-Wilhelmy, S.A.; Norby, R.J.; Zhang, H.; Finzi, A.C.; Lerdau, M.T. Increased mercury in forest soils under elevated carbon dioxide. Oecologia 2008, 158, 343-354. [CrossRef] [PubMed]

94. Rajkumar, M.; Prasad, M.N.V.; Swaminathan, S.; Freitas, H. Climate change driven plant-metal-microbe interactions. Environ. Int. 2013, 53, 74-86. [CrossRef] [PubMed]

95. Pandey, A.K.; Pandey, S.D.; Misra, V. Stability constants of metal-humic acid complexes and its role in environmental detoxification. Ecotoxicol. Environ. Saf. 2000, 47, 195-200. [CrossRef] [PubMed]

96. Steffen, W.; Hughes, L.; Alexander, D.; Rice, M. Cranking up the Intensity: Climate Change and Extreme Weather Events; Climate Council: Australia, 2017.

97. Hoyle, F.C.; Baldock, J.A.; Murphy, D.V. Soil organic carbon-Role in rainfed farming systems. In Rainfed Farming Systems; Tow, P., Cooper, I., Partridge, I., Birch, C., Eds.; Springer: Dordrecht, The Netherlands, 2011; pp. 339-361.

98. Zhang, Q.; Jiang, X.; Tong, D.; Davis, S.J.; Zhao, H.; Geng, G.; Feng, T.; Zheng, B.; Lu, Z.; Streets, D.G.; et al. Transboundary health impacts of transported global air pollution and international trade. Nature 2017, 543, 705. [CrossRef] [PubMed]

99. Itahashi, S.; Uno, I.; Osada, K.; Kamiguchi, Y.; Yamamoto, S.; Tamura, K.; Wang, Z.; Kurosaki, Y.; Kanaya, Y. Nitrate transboundary heavy pollution over East Asia in winter. Atmos. Chem. Phys. 2017, 17, 3823-3843. [CrossRef] 
100. Casazza, M.; Lega, M.; Liu, G.; Ulgiati, S.; Endreny, T.A. Aerosol pollution, including eroded soils, intensifies cloud growth, precipitation, and soil erosion: A review. J. Clean. Prod. 2018, 189, 135-144. [CrossRef]

101. Kapoor, V.; Li, X.; Elk, M.; Chandran, K.; Impellitteri, C.A.; Santo Domingo, J.W. Impact of heavy metals on transcriptional and physiological activity of nitrifying bacteria. Environ. Sci. Technol. 2015, 49, 13454-13462. [CrossRef] [PubMed]

102. Wang, Y.; Shi, J.; Wang, H.; Lin, Q.; Chen, X.; Chen, Y. The influence of soil heavy metals pollution on soil microbial biomass, enzyme activity, and community composition near a copper smelter. Ecotoxicol. Environ. Saf. 2007, 67, 75-81. [CrossRef] [PubMed]

103. Chen, J.; Zhou, H.C.; Pan, Y.; Shyla, F.S.; Tam, N.F.-Y. Effects of polybrominated diphenyl ethers and plant species on nitrification, denitrification and anammox in mangrove soils. Sci. Total Environ. 2016, 553, 60-70. [CrossRef] [PubMed]

104. Moss, B.; Kosten, S.; Meerhoff, M.; Battarbee, R.W.; Jeppesen, E.; Mazzeo, N.; Havens, K.; Lacerot, G.; Liu, Z.; De Meester, L.; et al. Allied attack: climate change and eutrophication. Inland Waters 2011, 1, 101-105. [CrossRef]

105. FOG, K. The effect of added nitrogen on the rate of decomposition of organic matter. Biol. Rev. 1988, 63, 433-462. [CrossRef]

106. Wedin, D.A.; Tilman, D. Influence of nitrogen loading and species composition on the carbon balance of grasslands. Science 1996, 274, 1720-1723. [CrossRef] [PubMed]

107. Thurston, J.M.; Williams, E.; Johnston, A. Modern developments in an experiment on permanent grassland started in 1856: Effects of fertilisers and lime on botanical composition and crop and soil analyses. Ann. Agron. (Fr.) 1976, 27, 1043-1082.

108. Lu, X.; Mao, Q.; Gilliam, F.S.; Luo, Y.; Mo, J. Nitrogen deposition contributes to soil acidification in tropical ecosystems. Glob. Chang. Biol. 2014, 20, 3790-3801. [CrossRef] [PubMed]

109. Van Breemen, N.; van Dijk, H.F.G. Ecosystem effects of atmospheric deposition of nitrogen in The Netherlands. Environ. Pollut. 1988, 54, 249-274. [CrossRef]

110. Jeppesen, E.; Kronvang, B.; Meerhoff, M.; Søndergaard, M.; Hansen, K.M.; Andersen, H.E.; Lauridsen, T.L.; Liboriussen, L.; Beklioglu, M.; Özen, A.; et al. Climate change effects on runoff, catchment phosphorus loading and lake ecological state, and potential adaptations. J. Environ. Qual. 2009, 38, 1930-1941. [CrossRef] [PubMed]

111. Hong, C.O.; Lee, D.K.; Chung, D.Y.; Kim, P.J. Liming effects on cadmium stabilization in upland soil affected by gold mining activity. Arch. Environ. Contam. Toxicol. 2007, 52, 496-502. [CrossRef] [PubMed]

112. Ok, Y.S.; Oh, S.-E.; Ahmad, M.; Hyun, S.; Kim, K.-R.; Moon, D.H.; Lee, S.S.; Lim, K.J.; Jeon, W.-T.; Yang, J.E. Effects of natural and calcined oyster shells on $\mathrm{Cd}$ and $\mathrm{Pb}$ immobilization in contaminated soils. Environ. Earth Sci. 2010, 61, 1301-1308. [CrossRef]

113. Naidu, R.; Kookana, R.S.; Sumner, M.E.; Harter, R.D.; Tiller, K.G. Cadmium sorption and transport in variable charge soils: A Review. J. Environ. Qual. 1997, 26, 602-617. [CrossRef]

114. McGowen, S.L.; Basta, N.T.; Brown, G.O. Use of diammonium phosphate to reduce heavy metal solubility and transport in smelter-contaminated soil. J. Environ. Qual. 2001, 30, 493-500. [CrossRef] [PubMed]

115. Seshadri, B.; Bolan, N.; Wijesekara, H.; Kunhikrishnan, A.; Thangarajan, R.; Qi, F.; Matheyarasu, R.; Rocco, C.; Mbene, K.; Naidu, R. Phosphorus-cadmium interactions in paddy soils. Geoderma 2016, 270, 43-59. [CrossRef]

116. Ge, L.-Q.; Cang, L.; Liu, H.; Zhou, D.-M. Effects of warming on uptake and translocation of cadmium (Cd) and copper $(\mathrm{Cu})$ in a contaminated soil-rice system under Free Air Temperature Increase (FATI). Chemosphere 2016, 155, 1-8. [CrossRef] [PubMed]

117. Wilson, M. The origin and formation of clay minerals in soils: Past, present and future perspectives. Clay Miner. 1999, 34, 7. [CrossRef]

118. Bergaya, F.; Lagaly, G. General introduction: Clays, clay minerals, and clay science. In Developments in Clay Science; Bergaya, F., Lagaly, G., Eds.; Elsevier: Amsterdam, The Netherlands, 2013; Volume 5, pp. 1-19.

119. Bergaya, F.; Lagaly, G. Introduction on modified clays and clay minerals. In Developments in Clay Science; Bergaya, F., Lagaly, G., Eds.; Elsevier: Amsterdam, The Netherlands, 2013; Volume 5, p. 383.

120. McAllister, L.E.; Semple, K.T. Role of clay and organic matter in the biodegradation of organics in soil. In Geomicrobiology: Molecular and Environmental Perspective; Barton, L.L., Mandl, M., Loy, A., Eds.; Springer: Dordrecht, The Netherlands, 2010; pp. 367-384. 
121. Zhu, D.; Zhong, H. Potential bioavailability of mercury in humus-coated clay minerals. J. Environ. Sci. 2015, 36, 48-55. [CrossRef] [PubMed]

122. Wijayawardena, M.A.A.; Megharaj, M.; Naidu, R. Exposure, toxicity, health impacts, and bioavailability of heavy metal mixtures. In Advances in Agronomy; Sparks, D.L., Ed.; Academic Press: Burlington, VT, USA, 2016; Volume 138, pp. 175-234.

123. Borrelli, P.; Robinson, D.A.; Fleischer, L.R.; Lugato, E.; Ballabio, C.; Alewell, C.; Meusburger, K.; Modugno, S.; Schütt, B.; Ferro, V.; et al. An assessment of the global impact of 21st century land use change on soil erosion. Nat. Commun. 2017, 8, 2013. [CrossRef] [PubMed]

124. Wiesmeier, M.; Munro, S.; Barthold, F.; Steffens, M.; Schad, P.; Kögel-Knabner, I. Carbon storage capacity of semi-arid grassland soils and sequestration potentials in northern China. Glob. Chang. Biol. 2015, 21, 3836-3845. [CrossRef] [PubMed]

125. Usman, A.; Kuzyakov, Y.; Stahr, K. Effect of clay minerals on immobilization of heavy metals and microbial activity in a sewage sludge-contaminated soil. J. Soils Sediments 2005, 5, 245-252. [CrossRef]

126. Biswas, B.; Sarkar, B.; McClure, S.; Naidu, R. Modified osmium tracer technique enables precise microscopic delineation of hydrocarbon-degrading bacteria in clay aggregates. Environ. Technol. Innov. 2017, 7, 12-20. [CrossRef]

127. Mandal, A.; Biswas, B.; Sarkar, B.; Patra, A.K.; Naidu, R. Surface tailored organobentonite enhances bacterial proliferation and phenanthrene biodegradation under cadmium co-contamination. Sci. Total Environ. 2016, 550, 611-618. [CrossRef] [PubMed]

128. Biswas, B.; Sarkar, B.; Rusmin, R.; Naidu, R. Mild acid and alkali treated clay minerals enhance bioremediation of polycyclic aromatic hydrocarbons in long-term contaminated soil: A14C-tracer study. Environ. Pollut. 2017, 223, 255-265. [CrossRef] [PubMed]

129. Biswas, B.; Sarkar, B.; Mandal, A.; Naidu, R. Heavy metal-immobilizing organoclay facilitates polycyclic aromatic hydrocarbon biodegradation in mixed-contaminated soil. J. Hazard. Mater. 2015, 298, 129-137. [CrossRef] [PubMed]

130. Ugochukwu, U.C.; Fialips, C.I. Removal of crude oil polycyclic aromatic hydrocarbons via organoclay-microbe-oil interactions. Chemosphere 2017, 174, 28-38. [CrossRef] [PubMed]

131. Singh, N.; Megharaj, M.; Gates, W.P.; Churchman, G.J.; Anderson, J.; Kookana, R.S.; Naidu, R.; Chen, Z.; Slade, P.G.; Sethunathan, N. Bioavailability of an organophosphorus pesticide, fenamiphos, sorbed on an organo clay. J. Agric. Food Chem. 2003, 51, 2653-2658. [CrossRef] [PubMed]

132. Xiaozhen, F.; Bo, L.; Aijun, G. Dynamics of solar light photodegradation behavior of atrazine on soil surface. J. Hazard. Mater. 2005, 117, 75-79. [CrossRef]

133. Mickan, B.S.; Abbott, L.K.; Fan, J.; Hart, M.M.; Siddique, K.H.M.; Solaiman, Z.M.; Jenkins, S.N. Application of compost and clay under water-stressed conditions influences functional diversity of rhizosphere bacteria. Biol. Fertil. Soils 2018, 54, 55-70. [CrossRef]

134. Burns, R.G.; DeForest, J.L.; Marxsen, J.; Sinsabaugh, R.L.; Stromberger, M.E.; Wallenstein, M.D.; Weintraub, M.N.; Zoppini, A. Soil enzymes in a changing environment: Current knowledge and future directions. Soil Biol. Biochem. 2013, 58, 216-234. [CrossRef]

135. Sarkar, B.; Singh, M.; Mandal, S.; Churchman, G.J.; Bolan, N.S. Clay minerals-Organic matter interactions in relation to carbon stabilization in soils. In The Future of Soil Carbon; Nannipieri, P., Hernandez, T., Eds.; Academic Press: Burlington, VT, USA, 2018; pp. 71-86.

136. Singh, B.; Schulze, D.G. Soil minerals and plant nutrition. Nat. Educ. Knowl. 2015, 6, 1.

137. Gislason, S.R.; Oelkers, E.H.; Eiriksdottir, E.S.; Kardjilov, M.I.; Gisladottir, G.; Sigfusson, B.; Snorrason, A.; Elefsen, S.; Hardardottir, J.; Torssander, P.; et al. Direct evidence of the feedback between climate and weathering. Earth Planet. Sci. Lett. 2009, 277, 213-222. [CrossRef]

138. Brady, P.V.; Carroll, S.A. Direct effects of $\mathrm{CO}_{2}$ and temperature on silicate weathering: Possible implications for climate control. Geochim. Cosmochim. Acta 1994, 58, 1853-1856. [CrossRef]

139. Frohne, T.; Rinklebe, J.; Diaz-Bone, R.A. Contamination of floodplain soils along the Wupper River, Germany, with $\mathrm{As}, \mathrm{Co}, \mathrm{Cu}, \mathrm{Ni}, \mathrm{Sb}$, and $\mathrm{Zn}$ and the impact of pre-definite redox variations on the mobility of these elements. Soil Sediment Contam. Int. J. 2014, 23, 779-799. [CrossRef]

140. Borch, T.; Kretzschmar, R.; Kappler, A.; Cappellen, P.V.; Ginder-Vogel, M.; Voegelin, A.; Campbell, K. Biogeochemical redox processes and their impact on contaminant dynamics. Environ. Sci. Technol. 2010, 44, 15-23. [CrossRef] [PubMed] 
141. Shand, P.; Grocke, S.; Creeper, N.L.; Baker, A.K.; Fitzpatrick, R.W.; Love, A.J. Impacts of climate change, climate variability and management on soil and water quality in wetlands of south australia. Procedia Earth Planet. Sci. 2017, 17, 456-459. [CrossRef]

142. Waring, B.; Hawkes, C.V. Ecological mechanisms underlying soil bacterial responses to rainfall along a steep natural precipitation gradient. FEMS Microbiol. Ecol. 2018, 94, fiy001. [CrossRef] [PubMed]

143. Allison, S.D.; Romero-Olivares, A.L.; Lu, Y.; Taylor, J.W.; Treseder, K.K. Temperature sensitivities of extracellular enzyme Vmax and Km across thermal environments. Glob. Chang. Biol. 2018, 24, 2884-2897. [CrossRef] [PubMed]

144. Hicks Pries, C.E.; Castanha, C.; Porras, R.C.; Torn, M.S. The whole-soil carbon flux in response to warming. Science 2017, 355, 1420-1423. [CrossRef] [PubMed]

145. Ma, Y.; Prasad, M.N.V.; Rajkumar, M.; Freitas, H. Plant growth promoting rhizobacteria and endophytes accelerate phytoremediation of metalliferous soils. Biotechnol. Adv. 2011, 29, 248-258. [CrossRef] [PubMed]

146. Tang, S.; Liao, S.; Guo, J.; Song, Z.; Wang, R.; Zhou, X. Growth and cesium uptake responses of Phytolacca americana Linn. and Amaranthus cruentus L. grown on cesium contaminated soil to elevated $\mathrm{CO}_{2}$ or inoculation with a plant growth promoting rhizobacterium Burkholderia sp. D54, or in combination. J. Hazard. Mater. 2011, 198, 188-197. [CrossRef] [PubMed]

147. Kim, S.; Kang, $\mathrm{H}$. Effects of elevated $\mathrm{CO}_{2}$ and $\mathrm{Pb}$ on phytoextraction and enzyme activity. Water Air Soil Pollut. 2011, 219, 365-375. [CrossRef]

148. Gao, Y.; Yang, Y.; Ling, W.; Kong, H.; Zhu, X. Gradient Distribution of root exudates and polycyclic aromatic hydrocarbons in rhizosphere soil. Soil Sci. Soc. Am. J. 2011, 75, 1694-1703. [CrossRef]

149. Ling, W.; Dang, H.; Liu, J. In situ gradient distribution of polycyclic aromatic hydrocarbons (PAHs) in contaminated rhizosphere soil: a field study. J. Soils Sediments 2013, 13, 677-685. [CrossRef]

150. Kuiper, I.; Lagendijk, E.L.; Bloemberg, G.V.; Lugtenberg, B.J.J. Rhizoremediation: A beneficial plant-microbe interaction. Mol. Plant-Microbe Interact. 2004, 17, 6-15. [CrossRef] [PubMed]

151. Hussain, I.; Puschenreiter, M.; Gerhard, S.; Schöftner, P.; Yousaf, S.; Wang, A.; Syed, J.H.; Reichenauer, T.G. Rhizoremediation of petroleum hydrocarbon-contaminated soils: Improvement opportunities and field applications. Environ. Exp. Bot. 2018, 147, 202-219. [CrossRef]

152. Nuccio, E.E.; Anderson-Furgeson, J.; Estera, K.Y.; Pett-Ridge, J.; de Valpine, P.; Brodie, E.L.; Firestone, M.K. Climate and edaphic controllers influence rhizosphere community assembly for a wild annual grass. Ecology 2016, 97, 1307-1318. [CrossRef] [PubMed]

153. Jackson, R.B.; Cook, C.W.; Pippen, J.S.; Palmer, S.M. Increased belowground biomass and soil $\mathrm{CO}_{2}$ fluxes after a decade of carbon dioxide enrichment in a warm-temperate forest. Ecology 2009, 90, 3352-3366. [CrossRef] [PubMed]

154. Oh, N.H.; Richter, D.D., Jr. Soil acidification induced by elevated atmospheric $\mathrm{CO}_{2}$. Glob. Chang. Biol. 2004, 10, 1936-1946.

155. Gray, C.W.; McLaren, R.G.; Roberts, A.H.C.; Condron, L.M. Effect of soil pH on cadmium phytoavailability in some New Zealand soils. N. Z. J. Crop Hortic. Sci. 1999, 27, 169-179. [CrossRef]

156. Öborn, I.; Jansson, G.; Johnsson, L. A field study on the influence of soil pH on trace element levels in spring wheat (Triticum aestivum), potatoes (Solanum tuberosum) and carrots (Daucus carota). Water Air Soil Pollut. 1995, 85, 835-840. [CrossRef]

157. Khalvati, M.; Dincer, I. Environmental impact of soil microorganisms on global change. In Causes, Impacts and Solutions to Global Warming; Dincer, I., Colpan, C.O., Kadioglu, F., Eds.; Springer: New York, NY, USA, 2013; pp. 233-250.

158. Krishnan, A.; Convey, P.; Gonzalez, M.; Smykla, J.; Alias, S.A. Effects of temperature on extracellular hydrolase enzymes from soil microfungi. Polar Biol. 2018, 41, 537-551. [CrossRef]

159. Tan, X.; Machmuller, M.B.; Wang, Z.; Li, X.; He, W.; Cotrufo, M.F.; Shen, W. Temperature enhances the affinity of soil alkaline phosphatase to Cd. Chemosphere 2018, 196, 214-222. [CrossRef] [PubMed]

160. Sardans, J.; Peñuelas, J.; Estiarte, M. Warming and drought change trace element bioaccumulation patterns in a Mediterranean shrubland. Chemosphere 2008, 70, 874-885. [CrossRef] [PubMed]

(C) 2018 by the authors. Licensee MDPI, Basel, Switzerland. This article is an open access article distributed under the terms and conditions of the Creative Commons Attribution (CC BY) license (http:/ / creativecommons.org/licenses/by/4.0/). 